\title{
A COMPARISON OF STUDENT VIEWS ON WEB-BASED AND FACE-TO-FACE HIGHER EDUCATION
}

\author{
Suleyman Nihat SAD (Corresponding Author) \\ Curriculum and Instruction, \\ Faculty of Education, Inonu University, Malatya, TURKEY \\ Ozlem GOKTAS \\ Doctoral Student, \\ Curriculum and Instruction, \\ Faculty of Education, Inonu University, Malatya, TURKEY \\ Ilhami BAYRAK \\ Doctoral Student, \\ Curriculum and Instruction, \\ Faculty of Education, Inonu University, Malatya, TURKEY
}

\begin{abstract}
The study aimed to describe and compare the perceptions of web-based distance education students and campus-based face-to-face students about the quality of education provided in their programs with regard to variables including gender, maritalstatus, and employment status. A baseline descriptive survey design and complementary ex post facto design were used in this study. A total of 536 students studying at two higher education institutions participated in the study. "Student Program Assessment Scale [SPAS]" was developed and used to assess web-based and face-to-face students' perceptions about the quality of education in their programs.
\end{abstract}

The results showed that web-based students were most positive about lifelong learning opportunities provided in their distance programs, followed by learning-teaching procedures, abilities to access and share resources, and lastly chances of cooperation and socialization. Face-to-face students were almost neutral in all aspects and, compared to web-based students, they were significantly less positive about lifelong learning opportunities (large effect size), learning-teaching procedures (medium effect size), and abilities to access and share resources (small effect size) provided by their programs.

Face-to-face and web-based learners were similarly and moderately positive about the cooperation and socialization opportunities provided in their programs. Gender, marital status and employment were found to cause no differences in practical sense on perceptions of web-based and face-to-face students.

Keywords: Distance education; web-based education; face-to-face education; higher education, curriculum evaluation. 


\section{INTRODUCTION}

Education has always been an essential need for human. Today this need is so comprehensive and urgent that present resources of either human or facility fail to satisfy the increased demands for education.

This bought about the parallel need to find innovative ways to educate more people. Thus, developments in technology have improved and changed the instructional technologies, and also introduced new disciplines in education including online education, e-learning, m-learning etc. One general discipline that considerably benefits from instructional technologies and principles of individualized learning, thus providing equal and lifelong learning opportunities is distance education (Kaya, Erden, Cakır, \& Bagırsakcl, 2004).

Distance education is the education that takes place synchronously or asynchronously through communication by means of instructional technologies where teachers and learners are in different places (Akdemir, 2011; Kaya et al., 2004; Isık, Isık, \& Guler, 2008; Isman, 1999; Odabas, 2003).

First notable distance education practices in higher education can be said to have begun with National Extension College (NEC) which paved the way to foundation of open university in England in 1974 (Cukadar \& Celik, 2003; Demiray, 1999). The aim was to provide individuals with financial shortcomings with the opportunity to study at high education (Cukadar \& Celik, 2003).

The concept of distance education was first discussed in Turkish education in the form of instruction via mail in a meeting held by the ministry in 1927, but this has not been realized until 1960 when a Center for Mail-based Instruction was founded (Cukadar \& Celik, 2003). A pioneering practice of distance education in higher education was in 1956 when Ankara University trained bank worker with mails (Demiray, 1999).

In 1981, the Board of Higher Education made it possible for the Turkish universities to implement distance education, and Anadolu University was the first to accept distance education students (Demiray, 1999). Today, several universities including Sakarya, Cukurova, Atatürk, METU, Cumhuriyet and Inonu have distant education faculties or programs.

While distance education was conventionally done in the form mail, books, television and radio, it took on a new dimension and gained further popularity with the introduction of internet (Horzum, 2007; Kışla et al., 2010).

The developments in internet infrastructure and availability of fast voice, picture and data transfer motivated people to communicate and share data on the net, and internetbased or online distance education has become an attractive alternative over its ancestors (Akdemir, 2011; Brown, 2012; Savas \& Arıcı, 2009).

So, the most common version of distance education today is internet- or web-based (distance) education (Erturgut, 2008; Odabas, 2003). Web-based education can also be defined as a combination of distance education and internet (Ozdil \& Celik, 2000; Sular, 2005). 
More comprehensively Odabas (2003, p. 24) defines web-based distance education as "the interactive exchange of data between distant students and faculty using advanced technological equipment." Through web-based distance education, students use internet to have access to lesson material, interact with the faculty and do their homework (Duzakın \& Yalcınkaya, 2008; Murphy \& Cifuentes, 2001).

An analysis of researches on web-based distance education reveals that it meets the contemporary education needs in many aspects. One major advantage of web-based distance education can be the ability for the learners to learn anywhere and anytime, thus meeting the need for further or lifelong learning (AI \& Mardan, 2004; Alkan, 1998; Arıkan, 2006; Deperlioğlu \& Yıldırım, 2009; Erdoğan, Bayram \& Deniz, 2007; Erturgut, 2008; Horzum, 2007; Hwang \& Chang, 2011; Isık et al., 2008; İşman, 2005; Ozonur \& Tekdal, 2004; Usluel \& Mazman, 2009). Brown (2012) found time constraint is the second most common reason for university students to prefer web-based courses.

Thus, web-based distance education provides individuals having time and space constraints with equal opportunities for education (Akca, 2006; Demir, 2008; Isbulan, 2008; Karaagaçlı \& Erden, 2008; Mısırlı, 2007). To illustrate, it enables someone working at a regular job to attend school without quiting their jobs (Akca, 2006; Balcl, 2008; Burma, 2008; Gok, 2011; Isık et al., 2008; Senyuva, 2007).

Moreover web-based distance education make savings from the cost of education removing various expenditures including transportation, accommodation, and catering (Çukadar \& Çelik 2003; Cukusic, Alfirevic, Granic, \& Garaca, 2010; Gokdemir, 2009; Misırlı, 2007; Odabas, 2003; Tanyeri \& Tufekci, 2010). It also makes extra financial savings such as commute time or parking troubles (Brown, 2012).

It facilitates increased student participation to learning process (Burma, 2008; Erturgut, 2008; Gokdemir, 2009; Isbulan, 2008) and motivates and attracts learners (Akca, 2006; Balcı, 2008; Burma, 2008; Demir, 2008; Gokdemir, 2009; Hwang \& Chang, 2011; Isbulan, 2008).

It improves research competences among learners (Burma, 2008; Erturgut, 2008). It enables learners to adjust their learning pace flexibly (Akca, 2006; Balcl, 2008; Burma, 2008; Erturgut, 2008; Gosper et al., 2010; Misırlı, 2007; Senyuva, 2007). Web-based distance learning provides individualized learning opportunities (Arıkan, 2006; Brown, 2012; Burma, 2008; Gok, 2011; Murphy \& Cfientes, 2011; Senyuva, 2007). It offers learning experiences corresponding with different learning styles (Arıkan, 2006; Burma, 2008; Gokdemir, 2009). Learners can have fast and easy access to the data they need (Burma, 2008). It facilitates effective interpersonal communication (Akca, 2006; Arıkan, 2006; Balcl, 2008; Gok, 2011; Tanyeri \& Tufekci, 2010). The content can be easily updated (Annagylyjov, 2006; Balcı, 2008; Burma, 2008; Mısırlı, 2007). From instructor's perspective, it may increase control over course and instruction, enabling better tracking, grading, and monitoring student progress (as cited in Brown, 2012). Because of these advantages web-based applications are perceived to make it easier to learn and help them achieve better results (Gosper et al., 2010; Jou, Chuang, \& Wu, 2010). Nevertheless, there are also researches putting that web-based learning does not cause a significant increase in academic achievement over face-to-face learning (Brown, 2012; Pierce, 2011; Thrasher, Coleman, Atkinson, 2011). 
Beside the strengths of web-based distance learning, some limitations have been also attributed to distance education in general and web-based distance education in particular. One major criticism is lack of socialization or learners' feeling lonely (Akca, 2006; Gokdemir, 2009; Karaagaclı \& Erden, 2008; Misırlı, 2007; Murphy \& Cfientes, 2011). Learners who are more concrete, practical and oriented toward facts and procedures may feel uneasy in a web-based learning atmosphere (Ku \& Chang, 2011). Some other constraints include poor teacher-learner communication (Akça, 2006; Mısırlı, 2007), disregarding the individual differences (Akca, 2006; Mısırlı, 2007), additional cost of having all learners possess a personal computer and internet access (Akca, 2006; Gokdemir, 2009; Mısırlı, 2007) or financial resources and infrastructure for the faculty (Surry, Grubb, Ensminger, \& Ouimette, 2009), lack of technical knowledge and skills among some learners to use the system effectively (Balcı, 2008; Erturgut, 2008; Gok, 2011; Murphy \& Cfientes, 2011), poor gains in applied courses or failure to achieve motor or affective objectives (Balcl, 2008; Erturgut, 2008; Senyuva, 2007), not fitting the learners who have not built individualized learning strategies or habits (Balcl, 2008; Senyuva, 2007). Also Brown (2012) mentions about failure to follow the courses on a regular basis can easily lead to falling behind and drop the course. Today higher education seems to be the degree web-based learning is used most commonly (Brown, 2012; Cukadar, 2008; Demir, 2008; Erturgut, 2008; Gosper et al., 2010; Ozonur \& Tekdal, 2004; Thrasher et al., 2011). Several higher education institutions including Anadolu, Sakarya, Cukurova, Atatürk, METU, Cumhuriyet and Inonu Universities. The very same universities also provide students with campus-based face-to-face higher education. In this study it was found worth investigating the perceptions of both web based and faceto-face higher education students about the quality of the education have. Such a comparison was expected to present results about the strengths of one kind of training over the other according to student perceptions. This comparison is also expected to yield results to be used for the evaluation of curricula implemented in both programs.

\section{PURPOSE OF THE STUDY}

The main purpose of this study was to describe and compare the perceptions of webbased distance education students and campus-based face-to-face students about the quality of education provided in their programs. In this study the indicators of quality of education were limited to cooperation and socialization opportunities, availability of accessing and sharing resources, quality of learning-teaching procedures and lifelong learning opportunities as represented in the research instrument. It was also aimed to analyze the students' views with regard to some variables including gender, maritalstatus, and employment status. In line with these purposes, answers to following questions were sought in the study:

$>$ How do the participating university students' perceive the quality of education provided in their programs?

$>$ Do the perceptions of web-based distance education students and face-toface education students differ significantly?

$>$ Do the perceptions of male and female students studying at web-based and face-to-face programs differ significantly?

$>$ Do the perceptions of married and single students studying at web-based and face-to-face programs differ significantly?

$>$ Do the perceptions of employed and unemployed students studying at web-based and face-to-face programs differ significantly? 


\section{METHOD}

\section{Design}

Since it was aimed to describe and compare the perceptions of web-based and face-toface students about the quality of education provided in their programs, a baseline descriptive survey design and a complementary casual-comparative or ex post facto design was used in this study. These designs are generally used in order to determine specific characteristics of the relevant population and to determine the possible causes for differences (Fraenkel, Wallen, \& Hyun, 2012).

\section{Research group}

A total of $\mathbf{5 3 6}$ students participated in the study, with $\mathbf{3 7 3}$ studying at Inonu University, Malatya and 163 studying at Cumhuriyet University, Sivas. These students were selected as per convenience sampling method where the group of individuals was conveniently available (Fraenkel et al., 2012) at the universities that researchers work. Among them 325 studied in face-to-face programs, while 211 attend the web-based distance education programs provided by Distance Learning Centers in both universities. A total of 351 students studied at Theology undergraduate/undergraduate completion programs, 10 studied in Surgical Nursery non-thesis master program, 83 studied in Business Management program, 56 studied in Public Administration program and 36 studied in Computer Programming program. Detailed information about participants is present in Table: 1.

Table 1:

Demographic information about the participants

\begin{tabular}{|c|c|c|c|}
\hline Variable & Group & $\mathbf{N}$ & $\%$ \\
\hline \multirow[t]{3}{*}{ University } & Inonu University (Malatya) & 373 & 69.6 \\
\hline & Cumhuriyet University (Sivas) & 163 & 30.4 \\
\hline & Total & 536 & 100,0 \\
\hline \multirow[t]{5}{*}{ Type of education } & Web-based distance & 211 & 39.4 \\
\hline & Face-to-face & 325 & 60.6 \\
\hline & Total & 536 & 100.0 \\
\hline & $\begin{array}{l}\text { Theology undergraduate/undergraduate } \\
\text { completion programs }\end{array}$ & 351 & 65,5 \\
\hline & Surgical Nursery Non-Thesis Master Program & 10 & 1,9 \\
\hline \multirow[t]{5}{*}{ Program } & Business Management & 83 & 15,5 \\
\hline & Computer Programming & 36 & 6,7 \\
\hline & Public Administration & 56 & 10,4 \\
\hline & Total & 536 & 100.0 \\
\hline & Female & 289 & 53,9 \\
\hline \multirow[t]{3}{*}{ Gender } & Male & 247 & 46,1 \\
\hline & Total & 536 & 100.0 \\
\hline & Married & 160 & 29,9 \\
\hline \multirow[t]{2}{*}{ Marital status } & Single & 376 & 70,1 \\
\hline & Total & 536 & 100,0 \\
\hline \multirow{3}{*}{ Employment status } & Employed & 176 & 32,8 \\
\hline & Unemployed & 360 & 67,2 \\
\hline & Total & 536 & 100,0 \\
\hline
\end{tabular}




\section{Instruments}

An instrument named "Student Program Assessment Scale [SPAS]" was developed to assess both web-based and face-to-face students' perceptions about the quality of education in their programs. The items in SPAS were written based on a large spectrum of quality assessment indicators concerning higher education including learning-teaching procedures, access to resources, lifelong learning opportunities, cooperation, socialization in general and various strengths and limitations of e-learning or distance learning in particular. In order to validate the content of the instrument an expert panel was established which included three colleagues specialized in distance education, curriculum development, and educational administration. They were requested to examine the content validity i.e. "the degree to which elements of [the] assessment instrument are relevant to and representative of the targeted construct for [the] particular assessment purpose [of the study]" (Haynes, Richard \& Kubany, 1995, p. 239). Based on the corrections and recommendations of the experts, the items were revised and initial form of SPAS including 51 items was completed.

The 5-point Likert type (Strongly agree-Strongly disagree) SPAS was then tested for construct validity and reliability with a pilot study administered on a total of 320 university students who attended either a web-based program $(n=120)$ or face-to-face programs $(n=200)$. Prior to exposing the 51-item scale to factor analysis, the sampling adequacy and normality of items were tested with KMO test, Bartlett Sphericity, and Skewness and Kurtosis coefficients. The results of KMO test $(0.88)$ and Bartlett test $\left(X^{2}=3482.03 ; p=.000\right)$ results verified the sampling adequacy of the data set for factorability. Also Skewness and Kurtosis coefficients ranging between \pm 1 for each item proved the normal distribution of the data set. Next, exploratory factor analysis was done using principal components method and Varimax rotation technique. As a result of the analysis, those items with low factor loadings $(<.40)$ and items with high loadings in multiple factors were discarded (Çokluk, Şekercioğlu, \& Büyüköztürk, 2010). In successive analyses $\mathbf{3 5}$ items were taken out of the instrument, and final analysis yielded a four factor structure with 16 items. The results of exploratory factor analysis and following reliability analyses were given in table: 2 .

Table 2

Results about factor analysis and reliability studies of SPAS

\begin{tabular}{|c|c|c|c|c|c|}
\hline & $\begin{array}{c}\text { Cooperation } \\
\text { and } \\
\text { Socialization } \\
\text { (4 items) }\end{array}$ & $\begin{array}{l}\text { Accessing and } \\
\text { sharing } \\
\text { resources } \\
\text { (4 items) }\end{array}$ & $\begin{array}{l}\text { Learning- } \\
\text { Teaching } \\
\text { Procedures } \\
\text { (5 items) }\end{array}$ & $\begin{array}{l}\text { Lifelong } \\
\text { learning } \\
\text { (3 items) }\end{array}$ & $\begin{array}{c}\text { Total } \\
\text { (16 items) }\end{array}$ \\
\hline Eigenvalues & 5.06 & 1.92 & 1.27 & 1.08 & \\
\hline $\begin{array}{l}\text { Total variance } \\
\text { explained }\end{array}$ & $17.16 \%$ & $15.88 \%$ & $13.78 \%$ & $11.56 \%$ & $58.4 \%$ \\
\hline Factor loadings & $\begin{array}{l}.736- \\
.812\end{array}$ & $\begin{array}{r}.604- \\
.788\end{array}$ & $\begin{array}{r}.585- \\
.716\end{array}$ & $\begin{array}{r}.564- \\
.740\end{array}$ & $\begin{array}{r}.564- \\
.812\end{array}$ \\
\hline $\begin{array}{l}\text { Cronbach } \\
\text { Alpha }\end{array}$ & .825 & .717 & .782 & .569 & .851 \\
\hline $\begin{array}{l}\text { Corrected } \\
\text { item-total } \\
\text { correlations }\end{array}$ & $\begin{array}{r}.607- \\
.681 \\
\end{array}$ & $\begin{array}{r}.324- \\
.656\end{array}$ & $\begin{array}{r}.493- \\
.582 \\
\end{array}$ & $\begin{array}{r}.369- \\
.432 \\
\end{array}$ & \\
\hline
\end{tabular}


The four-factor structure including "cooperation and socialization" (4 items), "accessing and sharing resources" (4 items), "learning-teaching procedures" (5 items) and "lifelong learning" ( 3 items) was found to account for $58.4 \%$ of the total variance. The factor loadings for all 16 items ranged between .564 and .812 .

The Cronbach Alpha coefficient was estimated .851 for entire scale, .825 for cooperation and socialization factor, .717 for accessing and sharing resources factor, .782 for learning-teaching procedures factor, and $\mathbf{5 6 9}$ for lifelong learning factor. This proves the internal consistency of the factors and entire scale as reliability values around .70 are adequate and values below .50 are unacceptable (Kline, 2011, p. 70). Also lack of low values (less than .30) among corrected item-total correlations (.324 - .681) indicates reliability of the scale (Pallant, 2007, p. 98). Cooperation and socialization factor measures students' level of satisfaction about the extent to which their program (webbased or face-to-face) provides opportunities to work in cooperation with peers and to socialize (e.g. (The program I attend) provides opportunities to have interaction between students.). Accessing and sharing resources factor inquires about students' satisfaction about the extent to which their program provides opportunities to have access to teachers or other resources to get or share information (e.g. (In the program I attend) it is difficult to have access to instructors.). Learning-teaching procedures factor contains items asking participants to evaluate their satisfaction about the quality of learning, teaching and evaluation procedures provided in

the program they attend (e.g. (In the program I attend) exams are done effectively).

Finally, the Lifelong Learning factor measures students' satisfaction about the extent to which their program provides opportunities to learn anytime and anywhere (e.g. People from different age groups can easily study at this program without any limitations). In order to interpret the scores from each factor comparatively, total scores were divided by the number of items in each factor yielding standard scores ranging from 1 to 5.Moreover, scores were interpreted according to the following equal intervals: 1.00$1.80=$ Strongly disagree; $1.81-2.60=$ Disagree; $2.61-3.40=$ Slightly agree; $3.41-4.20=$ Agree; 4.21-5.00=Strongly agree). In line with the research questions, the data were analyzed using descriptive statistics (mean scores), independent samples $t$ test, two way ANOVA, one way ANOVA (or Brown-Forsythe when homogeneity of variances not assumed), Post Hoc test of Scheffe (or Dunnett's C when homogeneity of variances not assumed). In inferential analysis significance level was regarded $p<.05$.

\section{RESULTS}

How Do the Participating University Students' Perceive

The Quality of Education Provided In Their Programs?

Web-based students were found to slightly agree $(\bar{X}=3.40)$ that their programs provide cooperation and socialization opportunities, whereas face-to-face students agreed $(\bar{X}=3.42)$ that their programs provide cooperation and socialization opportunities. The mean scores for the items also ranged between the intervals of slight agreement $\left(\bar{X}_{\min }=3.25\right)$ and agreement $\left(\bar{X}{ }_{\max }=3.55\right)$ for both web-based and face-to-face programs. The mean scores from accessing and sharing resources factor indicated agreement $(\bar{X}=3.47)$ for web-based students, but slight agreement $(\bar{X}=3.27)$ for face-to-face students. Similarly, the items in the factor were scored ranging between agreement ( $\bar{X}$ max $=3.52$ ) (mostly by web-based students) and slight agreement ( $\bar{X}$ min $=3.12$ ) (mostly by face-to-face students). 
Web-based students were found to agree $(\bar{X}=3.62)$ that their programs provide quality teaching and learning procedures, whereas face-to-face students slightly agreed $(\bar{X}=3.08)$ that their programs can do so. The mean scores for the items also ranged between slight agreement $\left(\bar{X}_{\min }=2.73\right)$ (especially for face-to-face students) and agreement $\left(\bar{X}_{\max }=4.12\right)$ (especially for web-based students).

The mean score from lifelong learning factor indicated strong agreement $(\bar{X}=4.31)$ for web-based students, but just agreement $(\bar{X}=3.42)$ for face-to-face students. The items in the factor were scored ranging between slight agreement $\left(\bar{X}_{\min }=3.07\right)$ (mostly by face-to-face students) and strong agreement $\left(\bar{X}_{\max }=4.62\right)$ (mostly by web-based students).

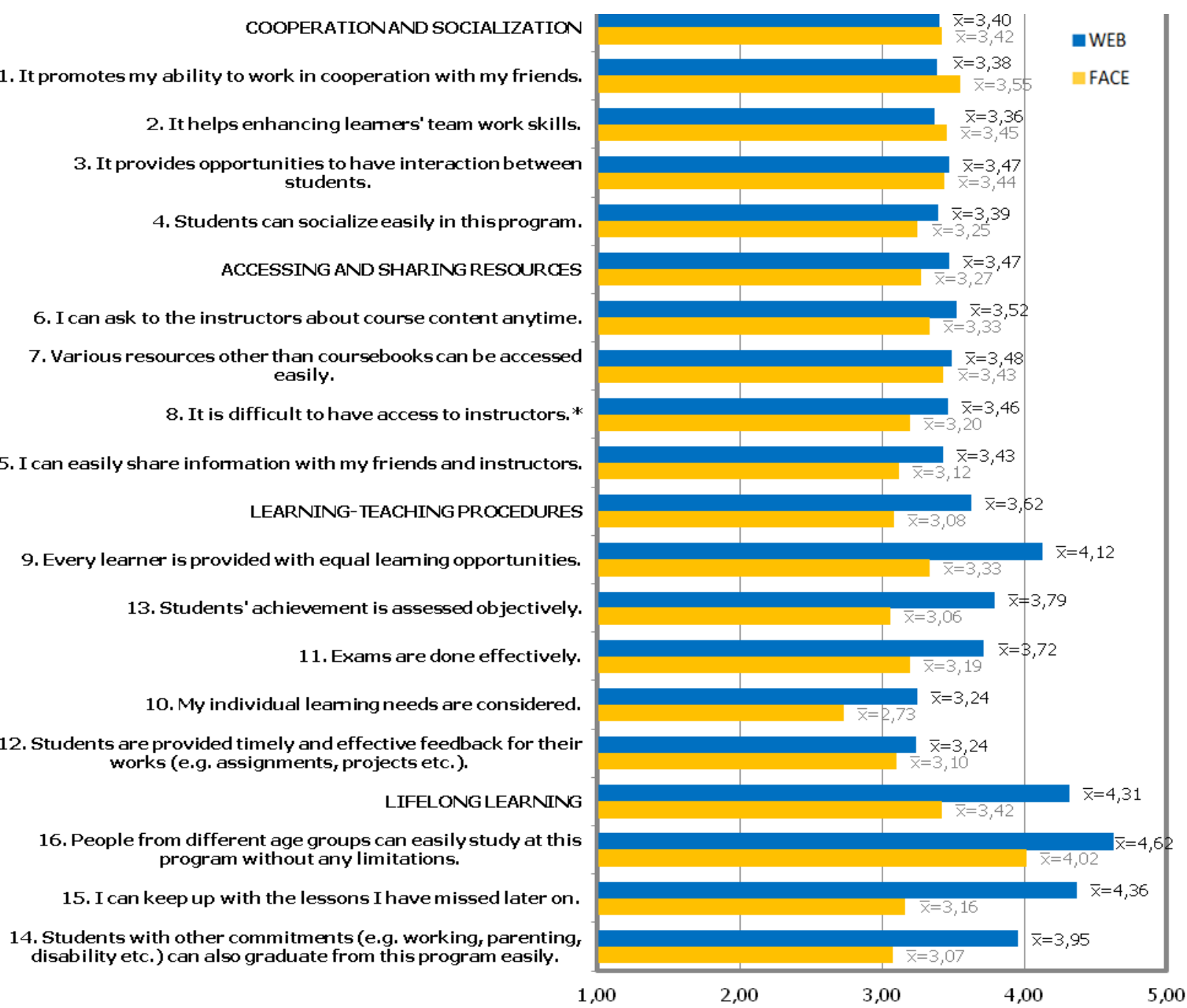

Figure: 1

Mean scores for items and factors regarding the students' perceptions about the quality of education in their programs $(\mathrm{N}=536)$ 
In overall scale, the item agreed the least by face-to-face students was "(In the program $I$ attend) $m y$ individual learning needs are considered." $\left(\bar{X}_{\min }=2.73\right)$ coinciding with slight agreement, while the item agreed the most by face-to-face students was "(The program I attend) promotes my ability to work in cooperation with my friends" $(\bar{X} \max =3.55)$ coinciding with agreement). The item agreed the least, on the other hand, by web-based students was again "(In the program $I$ attend) my individual learning needs are considered." ( $\left.\bar{X}{ }_{\min }=3.24\right)$ and "(In the program I attend) students are provided timely and effective feedback for their works (e.g. assignments, projects etc.)." $\left(\bar{X}_{\min }=3.24\right)$, both coinciding with slight agreement. The highest scores in the scale belonged to items "People from different age groups can easily study at this program without any limitations" ( $\bar{X} \max =4.62$ ) and "I can keep up with the lessons $I$ have missed later on" ( $\bar{X} \max =4.36)$, both of which were agreed strongly by web-based students.

Do the Perceptions of Web-Based Distance Education Students

And Face-To-Face Education Students Differ Significantly?

The $t$ test analysis revealed that web-based and face-to-face students' views on cooperation and socialization opportunities provided by their programs did not differ statistically significantly $\left[t_{(386,62)}=.232 \mathrm{p}=.817\right]$. However, their views differed statistically significantly for remaining factors in favor of web-based students: accessing and sharing resources $\left[t_{(387,028)}=2.763, p=.008\right]$, learning-teaching procedures $\left[t_{(534)=}\right.$ $7.37, p=.006]$, and lifelong learning $\left[t_{(534)=14.55,} p=.000\right]$. A comparison of mean scores suggested that, compared to face-to-face students, web-based students perceive that their programs provide better opportunities regarding accessing and sharing resources $\left(\bar{X}_{\text {(web) }}=3.47>\bar{X}\right.$ (face) $\left.=3.27\right)$, learning-teaching procedures $\left(\bar{X}_{\text {(web) }}=3.62>\right.$ $\bar{X}$ (face) $=3.08$ ), and lifelong-learning $\left(\bar{X}_{\text {(web) }}=4.31>\bar{X}_{\text {(face) }}=3.42\right)$. The effect sizes for these differences were estimated small for accessing and sharing resources (Cohen $\mathrm{d}=$ .23 and $\eta^{2}=.01$ ), medium for learning-teaching procedures (Cohen $d=.65$ and $\eta^{2}=.09$ ) and large for lifelong learning factor (Cohen $\mathrm{d}=1.29$ ve $\eta^{2}=.28$ ). Thus the statistical difference for accessing and sharing resources is questionable in practice, while the differences for learning-teaching procedures and especially lifelong learning can be considered significant in practical terms as well.

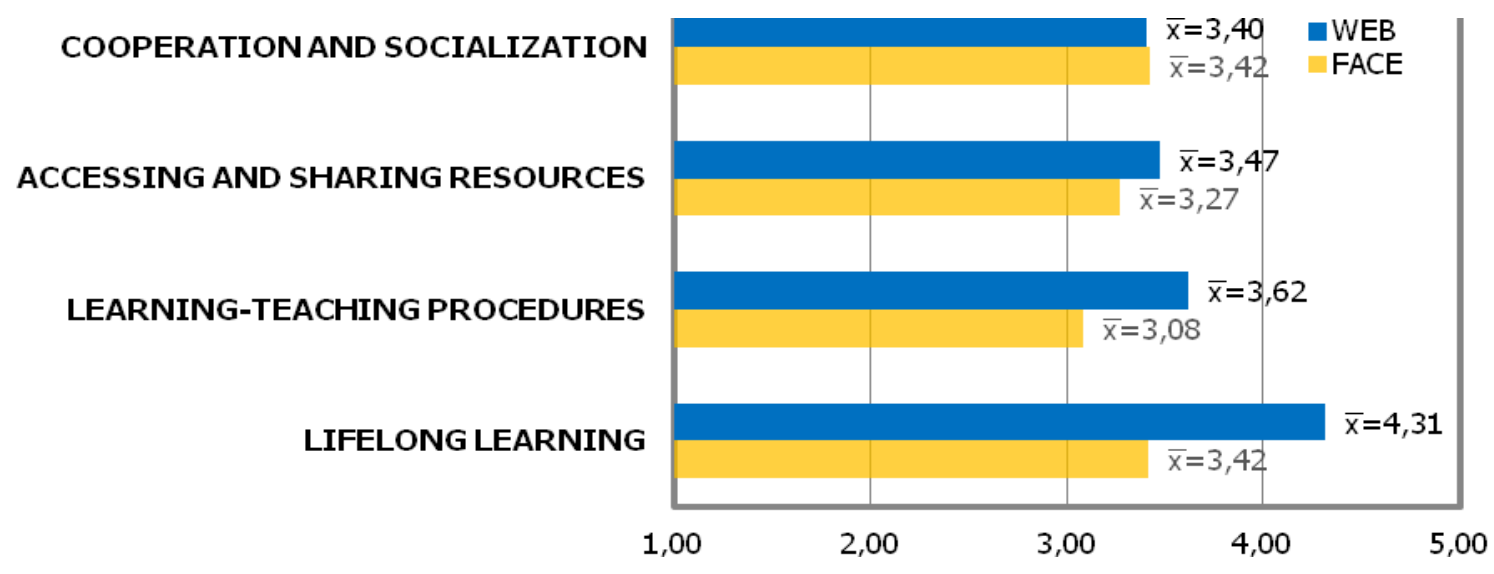

Figure: 2

Mean scores for factors regarding the students' perceptions about the quality of education in their programs $(N=536)$ 
Do the Perceptions of Male and Female Students Studying at Web-Based And Face-To-Face Programs Differ Significantly?

The two way ANOVA revealed that main effect of gender on students' views was not statistically significant for neither factors: cooperation and socialization $\left(F_{(1,532)}=, 357\right.$; $p=, 551)$, accessing and sharing resources $\left(F_{(1,532)}=, 328 ; p=, 567\right)$, learning-teaching procedures $\left(F_{(1,532)}=, 458 ; p=, 499\right)$, and lifelong learning $\left(F_{(1,532)}=, 950 ; p=, 330\right)$. Similarly, no statistically significant interaction effect of Type of education * Gender was observed on students' views regarding accessing and sharing resources $\left(F_{(1,532)}=, 345\right.$; $\mathrm{p}=, 557)$, learning-teaching procedures $\left(\mathrm{F}_{(1,532)}=, 015 ; \mathrm{p}=, 902\right)$, and lifelong learning $\left(F_{(1,532)}=, 248 ; p=, 619\right)$. However, for views on cooperation and socialization, $a$ statistically significant interaction effect of Type of education * Gender was established $\left(F_{(1,532)}=7,577 ; p=, 006 *\right)$ (see Table 3-4).

That means the influence of type of education (web or face) on students' views depends on gender.

Table: 3

Descriptive statistics for cooperation and socialization factor by type of education and gender

\begin{tabular}{|c|c|c|c|c|c|c|c|c|c|}
\hline & Female & & & Male & & & Total & & \\
\hline & $\bar{X}$ & $\mathbf{s}$ & $\mathbf{N}$ & $\bar{X}$ & $\mathbf{s}$ & $\mathbf{N}$ & $\bar{X}$ & $\mathbf{s}$ & $\mathbf{N}$ \\
\hline $\begin{array}{l}\text { Face-to-face } \\
\text { Web-based } \\
\text { Total }\end{array}$ & $\begin{array}{l}3,54 \\
3,32 \\
3,46 \\
\end{array}$ & $\begin{array}{l}0,80 \\
0,96 \\
0,87\end{array}$ & $\begin{array}{l}181 \\
108 \\
289 \\
\end{array}$ & $\begin{array}{l}3,28 \\
3,49 \\
3,37\end{array}$ & $\begin{array}{l}0,78 \\
0,99 \\
0,88\end{array}$ & $\begin{array}{l}144 \\
103 \\
247\end{array}$ & $\begin{array}{l}3,42 \\
3,40 \\
3,41\end{array}$ & $\begin{array}{l}0,80 \\
0,98 \\
0,87\end{array}$ & $\begin{array}{l}325 \\
211 \\
536\end{array}$ \\
\hline
\end{tabular}

Table: 4

Two way ANOVA results for interaction effect of Type of education * Gender on views about cooperation and socialization

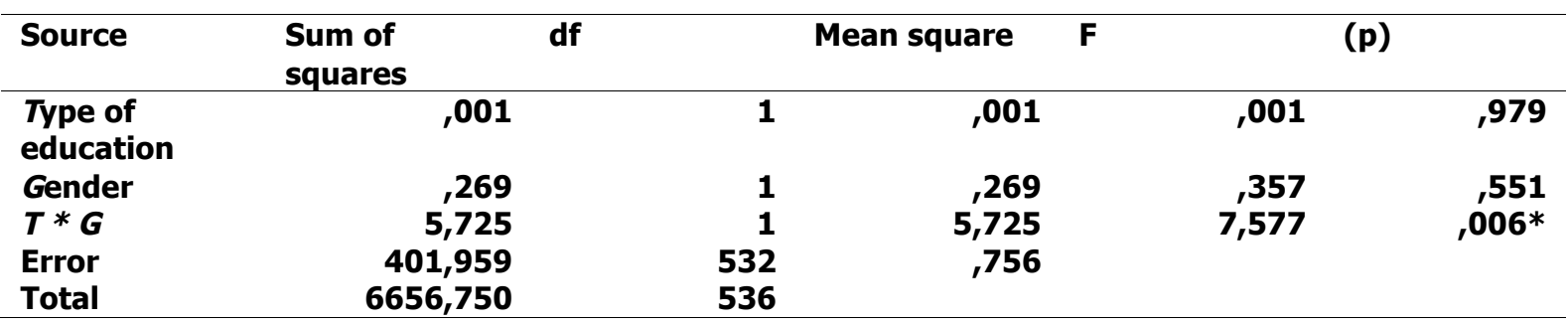

The post-hoc one way ANOVA test was done in order to find the source of the difference observed depending on the interaction effect of Type of education * Gender. The one way ANOVA (Brown-Forsythe $=2.849, p=.037$ ) and following Dunnett $C$ tests revealed a statistically significant difference between female students studying at face-to-face programs $(\bar{X}=3.54)$ and male students studying at face-to-face programs $(\bar{X}=3.28)$ in favor of the former.

Though this suggests that female face-to-face students find their programs statistically more cooperative and social than their male friends do, the estimated small effect size $\left(n^{2}=.01\right)$ makes this difference questionable in practice. 
Do the Perceptions of Married and Single Students Studying at Web-Based and Face-To-Face Programs Differ Significantly?

The two way ANOVA revealed that main effect of marital status on students' views was not statistically significant for any factors, but cooperation and socialization $\left(F_{(1,532)}\right.$ $=5.380 ; p=.021)$. The comparison of mean scores suggested that generally married students $(n=160, \bar{X}=3.48)$ find their program statistically more cooperative and social than single students do $(n=376, \bar{X}=3.39)$. Yet, the estimated small effect size $\left(n^{2}=.010\right)$ implies that this difference is not practically significant. Moreover, no statistically significant interaction effect of Type of education * Marital Status was observed on students' views regarding cooperation and socialization $\left(F_{(1,532)}=1.847 ; p=.175\right)$, accessing and sharing resources $\left(F_{(1,532)}=, 609 ; p=, 436\right)$, learning-teaching procedures $\left(F_{(1,532)}=.507 ; p=.477\right)$, and lifelong learning $\left(F_{(1,532)}=.804 ; p=.370\right)$.

Do the Perceptions of Employed and Unemployed Students Studying

At Web-Based And Face-To-Face Programs Differ Significantly?

The two way ANOVA revealed that main effect of employment status on students' views was not statistically significant for neither factors: cooperation and socialization $\left(F_{(1,532)}\right.$ $=.004 ; \mathrm{p}=.949)$, accessing and sharing resources $\left(\mathrm{F}_{(1,532)}=.376 ; \mathrm{p}=.540\right)$, learningteaching procedures $\left(F_{(1,532)}=.493 ; p=.483\right)$, and lifelong learning $\left(F_{(1,532)}=3.116 ; p=\right.$ .078). Similarly, no statistically significant interaction effect of Type of education * Employment status was observed on students' views regarding cooperation and socialization $\left(F_{(1,532)}=1.265 ; p=.261\right)$, accessing and sharing resources $\left(F_{(1,532)}=.863\right.$; $\mathrm{p}=.353)$, learning-teaching procedures $\left(\mathrm{F}_{(1,532)}=.269 ; \mathrm{p}=.604\right)$, and lifelong learning $\left(F_{(1,532)}=.379 ; p=.538\right)$.

\section{DISCUSSION AND CONCLUSIONS}

This study aimed to analyze the evaluative perceptions of distance (web-based) and campus-based (face-to-face) higher education students about their programs from such aspects as cooperation and socialization, accessing and sharing resources, learningteaching procedures, and lifelong learning opportunities. Web-based students were most positive about lifelong learning opportunities provided in their distance programs, followed by learning-teaching procedures, abilities to access and share resources, and lastly the cooperation and socialization opportunities. Campus-based face-to-face students were almost neutral in all aspects and, compared to web-based students, they were significantly less positive about lifelong learning opportunities (large effect size), learning-teaching procedures (medium effect size), and abilities to access and share resources (small effect size) provided in their programs. Face-to-face and web-based learners were similarly and moderately positive about the cooperation and socialization opportunities provided in their programs.

This finding suggesting that web-based learners also feel socialized as much as face-toface students seems paradoxical considering the general notion that distance education brings lack of socialization or learners' feeling lonely (Akca, 2006; Gokdemir, 2009; Karaagaclı \& Erden, 2008; Mısırlı, 2007; Murphy \& Cifuentes, 2001). On the other hand, one may infer that face-to-face students may not also find opportunities to socialize enough. Lastly, such variables as gender, marital status and employment were found to cause no differences in practical sense on perceptions of web-based and face-to-face students. 
Most remarkable advantage of both web-based and face-to-face programs was perceived to be the provision of opportunities to individuals from various age groups to study without any limitations.

However, both programs, web-based and face-to-face, were found to meet the students' individual learning needs the least. Welcoming all age groups is a natural characteristic of higher education in general, but by nature web-based distance education welcomes more (Gokdemir, 2009; Karaagaclı \& Erden, 2008; Mısırlı, 2007).

On the other hand, meeting the learner needs depends more on the instructor's performance. Since the same instructors are teaching in both programs, the failure to meet students' individual needs may be attributed to the poor performance of instructors in designing diversified content and materials for large groups of students (Mısırlı, 2007).

The results in general suggested that most remarkable advantages (considering the large and medium effect sizes of the perception differences) of web-based programs over faceto-face programs were favorable lifelong-learning and learning-teaching opportunities, respectively. Considering that distance education, by its nature, is characterized with provision of opportunities to learn independent of time and place, this finding is everything but surprising.

Web-based education is frequently reported by learners as a flexible resort in face of time and space constraints e.g. lack of time, family responsibilities, and travel burden (Brown, 2012). This flexibility was represented here in the form of easy participation into higher education by different age groups and people with other commitments, as well as the ease to keep up with the lessons missed, which, as Gosper et al. (2010) found, was perceived as the most remarkable advantage of web-based learning.

Also findings regarding better learning-teaching procedures (especially in terms of equal learning opportunities, objective assessment and effective exams) provided in webbased programs were consistent with those by Gosper et al. (2010) who found that most students agreed web-based lecture technologies made it easier to learn.

As a limitation of this study, students' actual academic achievements were not compared, thus the perception regarding better learning can be misleading. For, web-based practices have not been reported as definite performance enhancers on the part of students (Brown, 2012; Pierce, 2011; Thrasher et al., 2011). Nevertheless, its combination with other effective strategies such as problem-based learning (Atan, Sulaiman \& Idrus, 2005), project-based interactive activities (Jou et al., 2010) has been reported to promote academic achievement. This once again brings forward the discussion about instructor's role in web-based or face-to-face.

No matter if it is web-based or face-to-face, it fails if instruction cannot make an impact on learners. Thus, if the faculty tends to replicate out-of-date methods of one-way lecturing they use in face-to-face settings, web-based instruction cannot be promising. As a matter of fact, Gosper et al. (2010) found that three fourth of faculty admitted they had not changed the structure of their course as a result of using web-based lecture technologies. This may imply just a shift in tool preserving the ineffective methodologies of face-to-face applications such as pure expository teaching. But web-based curriculum needs a complete change from in-class curriculum. 
In improving the quality of web-based education, faculty is expected to adapt and change to meet the requirements of web-based instruction. Hence, the ICT competencies of the faculty should not be underestimated.

As Gholami and Sayadi (2012) report especially those faculty with high rates of internet use perceive web-based instruction less challenging, but otherwise it is perceived more challenging than facilitating. But this may have some resistance.

Lastly, considering the web-based learners' perceptions about better learning-teaching and lifelong learning opportunities, face-to-face programs may develop some blended practices or courses.

Thus face-to-face students can also enjoy such opportunities as ease to keep up with the lessons they have missed, objective assessment or equal learning opportunities as webbased learners can do.

Authors Note: Findings of this research were also presented at the $2^{\text {nd }}$ National Congress on Curriculum and Instruction held in Bolu Abant İzzet Baysal University on 27-29 September 2012.

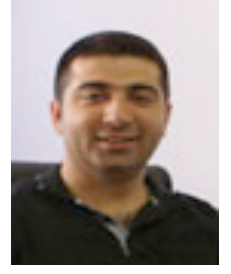

\section{BIODATA and CONTACT ADDRESSES of the AUTHORS}

Süleyman Nihat SAD is an associate professor at the Department of Curriculum and Instruction in Inonu University. His main research interests include curriculum development and evaluation, instructional methods, instructional technologies, parental involvement, teaching English to young learners, and qualitative and quantitative research methodologies.

Süleyman Nihat SAD (Corresponding Author)

Curriculum and Instruction, Faculty of Education,

Inonu University, Malatya, Turkey

TR 44800, Malatya, TURKEY

Phone: +90 422-341-0010 Ext.4488

Mobile: +90 5426424583

Email: nihat.sad@inonu.edu.tr

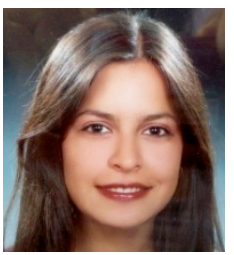

Ozlem GOKTAS is a mathematics teacher working in Malatya. She is also a doctoral student at the Department of Curriculum and Instruction in Inonu University. Her main research interests include mathematics education, measurement and evaluation.

\section{Ozlem GOKTAS}

Doctoral Student, Curriculum and Instruction, Faculty of Education, Inonu University, Malatya, TURKEY

44800, Malatya, TURKEY

E-mail: ozlemgoktas44@hotmail.com 


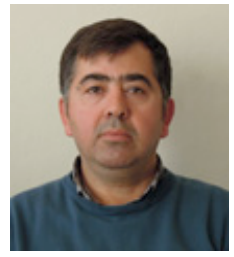

Ilhami BAYRAK is a counseling and guidance teacher and a doctoral student at the Department of Curriculum and Instruction in Inonu University. He is currently working at Cumhuriyet University as an instructor.

\author{
Ilhami BAYRAK \\ Doctoral Student, Curriculum and Instruction, \\ Faculty of Education, Inonu University, \\ Malatya, TURKEY \\ 44800, Malatya, TURKEY \\ Email: ilhamibay27@hotmail.com
}

\title{
REFERENCES
}

Akca, 0. (2006). SAÜ uzaktan eğitim öğrencilerinin iletişim engellerli ile ilgili öğrenci görüşleri [Demands of the SAU distance education students according to communication barriers.]. Unpublished master thesis. Sakarya University, Sakarya, Turkey.

Akdemir, 0. (2008). Teaching in online courses: Experiences of instructional technology faculty members. Turkish Online Journal of Distance Education, 9(2) 97-108, Eskisehir, Turkey.

Al, U. \& Mardan, R. O. (2004). Web tabanlı uzaktan eğitim sistemleri: sahip olması gereken özellikler ve standartlar [Web-based distance education systems: required features and standards]. Bilgi Dünyası, 5(2), 259-271, Turkey.

Alkan, C. (1998). Eğitim teknolojisi ve uzaktan eğitimin kavramsal boyutları [The conceptual dimentions of educational technologies and distance education]. Ankara: Unal Ofset Matbaaları, Turkey.

Annagylyjov, Y. (2006). Assessing the expository differences between traditional education and virtual class based education. Unpublished master thesis. Gazi University, Ankara, Turkey.

Arıkan, Y. D. (2006). Web destekli etkin öğrenme uygulamalarının öğretmen adaylarının derse yönelik tutumları üzerindeki etkileri [The effects of web-supported active learning activities on teacher trainees' attitudes towards course]. Ege Eğitim Dergisi, 7(1), 23-41, İzmir, Turkey.

Atan, H., Sulaiman, F., \& Idrus, R.M. (2005). The effectiveness of problem-based learning in the web-based environment for the delivery of an undergraduate physics course. International Education Journal, 6(3), 430-437.

Balcı, M. (2008). Karma öğrenme ile ilgili öğrenci görüşleri [Students' opinions on blended learning]. Unpublished master thesis. Hacettepe University, Ankara, Turkey.

Brown, J. L. M. (2012). Online learning: a comparison of web-based and land-based courses. Quarterly Review of Distance Education, 13(1), 39-42. 
Burma, Z. A. (2008). AB'ye geçiş sürecinde meslek elemanlarinin uzaktan öğretim ile eğitimi [Training of Professional Employees via the distance learning method within the EU entrance process]. Bilişim Teknolojileri Dergisi, 1(2), 15-20, Turkey.

Cukusic, M., Alfirevic, N., Granic, A., \& Garaca, Z. (2010). E-learning process management and the e-learning performance: Results of a European empirical study. Computers \& Education 55, 554-565.

Çokluk, O., Sekercioğlu, G., \& Büyüköztürk, S. (2010). Sosyal bilimler için çok değişkenli istatistik: Spss ve Lisrel uygulamaları [Multivariate statistics for social sciences: Spss and Lisrel applications]. Ankara: PegemA Akademi, Turkey.

Çukadar, S. \& Çelik, S. (2003). İnternete dayalı uzaktan öğretim ve üniversite kütüphaneleri [Web-based distance learning and university libraries]. Doğuş Üniversitesi Dergisi, 4(1), 31-42, Turkey.

Demir, Z. (2008). Uzaktan eğitim öğrencilerinin akademik güdülenme düzeyleri (SAÜ Örneği) [The student's level of academic motivation in distance education]. Unpublished master thesis. Sakarya University, Sakarya.

Demiray, U. (1999). Açıköğretim fakültesi mezunlarının çalışma yaşamı ile ilişkileri [The relations of open education faculty graduates with working life]. May, Eskisehir. Elektronik ISBN 975 98590-4-1, Eskisehir, Turkey.

Deperlioglu, O. \& Yıldırım, R. (2009). Mesleki eğitimin uzaktan eğitim ile desteklenmesi ve örnek uygulama [Support the professional training with distance learning and an example for the implementation]. AKÜ Fen Bilimleri Dergisi, 1, 61-70, Turkey.

Duzakın, E. \& Yalcınkaya, S. (2008). Web tabanlı uzaktan eğitim sistemi ve Çukurova üniversitesi öğretim elemanlarının yatkınlıkları [Web based distance learning system and distance learning familiarities among members of the Cukurova University]. C..̈̈. Sosyal Bilimler Enstitüsü Dergisi, 17(1), 225-244, Adana, Turkey.

Erdogan, Y., Bayram, S. \& Deniz, L. (2007). Web tabanlı öğretim tutum ölçeği: Açıklayıcı ve doğrulayıcı faktör analizi çalışması [Web based instruction attitude scale:

Explanatory and confirmatory factor analyses]. Uluslararası İnsan Bilimleri Dergisi, $4(2)$, 1-14, Ankara, Turkey.

Erturgut, R. (2008). İnternet temelli uzaktan eğitimin örgütsel, sosyal, pedagojik ve teknolojik bileşenleri [Organizational, social, pedagogic components of the internet basic distance education]. Bilişim Teknolojileri Dergisi, 1(2), 79-85, Turkey.

Fraenkel, J. R., Wallen, N. E., \& Hyun, H. H. (2012). How to design and evaluate research in education ( $8^{\text {th }}$ ed.). New York, USA: McGraw-Hill.

Gosper, M., McNeill, M., Phillips, R., Preston, G., Woo, K., \& Green, D. (2010) Web-based lecture technologies and learning and teaching: a study of change in four Australian universities. ALT-J, Research in Learning Technology, 18(3), 251-263. 
Gok, B. (2011). Uzaktan eğitimde görev alan öğretim elemanlarının uzaktan eğitim algısı [Perceptions of faculty percieve the current status of distance education]. Unpublished master thesis. Gazi University, Ankara.

Godemir, A. (2009). İnternet tabanlı uzaktan eğitim sistemi geliştirilmesi: Öğrenme modüllerinin oluşturulmasında Robert Gagne'nin öğrenme adımlarının kullanılması [The development of internet based distance education system: Using Robert Gagne's nine events to create learning modules]. Unpublished master thesis. Karaelmas University, Zonguldak, Turkey.

Haynes, S.N., Richard, D.C.S., \& Kubany, E.S. (1995). Content validity in psychological assessment: a functional approach to concepts and methods. American Psychological Association, 7(3), 238-247.

Horzum, M. B. (2007). Web tabanlı yeni öğretim teknolojileri: web 2.0 araçları [Web based new instructional technologies: web 2.0 tools]. Eğitim Bilimleri ve Uygulama, 6 (12), 99-121, Ankara, Turkey.

Hwang, G. J. \& Chang, H. F. (2011). A formative assessment-based mobile learning approach to improving the learning attitudes and achievements of students. Computers \& Education, 56, 1023-1031.

Isbulan, O. (2008). Uzaktan eğitim web sitesinin kullanılabilirlik düzeyi (SAÜ örneği) [The usability level of distance education's web site (SAU sample)]. Unpublished master thesis. Sakarya University, Sakarya, Turkey.

Isman, A. (2005). Uzaktan Eğitim, 2.Baskı [Distance Education, $2^{\text {nd }}$ edition]. Ankara: PegemA Yayınları.

Isık, I., Isık, A. H., \& Güler, I. (2008). Uzaktan eğitimde üç boyutlu web teknolojilerinin kullanılması [Using the $3 \mathrm{~d}$ web technologies in distance education]. Bilişim Teknolojileri Dergisi, 1(2), 79-85, Turkey.

Jou, M., Chuang, C., \& Wu, Y. (2010). Creating interactive web-based environments to scaffold creative reasoning and meaningful learning: from physics to products. Turkish Online Journal of Educational Technology-TOJET, 9(4), 49-57, Sakarya, Turkey.

Karaagaclı, M. \& Erden, 0. (2008). Internet destekli uzaktan eğitimde dokuz aşamalı ögretim durumunun tasarımı [The design of the nine-level learning situation in the distance education supported with internet technologies]. Bilişim Teknolojileri Dergisi, 1(2), 21-29.

Kaya, Z., Erden, O., Çakır, H. \& Bağırsakcı, B. (2004). Uzaktan eğitimin temelleri dersindeki uzaktan eğitim ihtiyacı ünitesinin web tabanlı sunumunun hazırlanması [Developing the web-based presentation of need for distance education unit in the fundamentals of distance education course]. The Turkish Online Journal of Educational Technology-TOJET, 3(3), 165-175, Sakarya, Turkey. 
Kısla, T., Sarsar, F., Arıkan, Y. D., Meshur, E., Sahin, M., \& Kokoç, M. (2010). Web tabanlı uzaktan eğitim sistemlerinde karşılaşılan problemler [Encountering problems of the webbased distance learning systems]. E-Journal of New World Sciences Academy, 5(1), 1-18, Turkey.

Kline, R. B. (2011). Principles and practice of structural equation modeling ( $3^{\text {rd }}$ ed.). New York London: The Guilford Press.

Ku, D.T., \& Chang, C. (2011). The effect of academic discipline and gender difference on Taiwanese college students' learning styles and strategies in web-based learning environments. Turkish Online Journal of Educational Technology, 10(3), 265-272, Sakarya, Turkey.

Mısırlı, Z. A. (2007). Web tabanlı öğrenme yönetim sistemine ilişkin öğrenci ve öğretmen görüşleri [Opinions of students and lecturers about web based learning managment system]. Unpublished master thesis. Balıkesir University, Balıkesir.

Murphy, K. L. \& Cifuentes, L. (2001). Using web tools, collaborating, and learning online. Distance Education, 22(2), 285-305.

Odabas, H. (2003). Internet tabanlı uzaktan eğitim ve bilgi ve belge yönetimi bölümleri [Internet based distance education and departments of information and records management]. Türk Kütüphaneciliği Dergisi, 17(1), 22-36, Ankara, Turkey.

Ozdil, B. \& Çelik, A. (2000). İnternete dayalı uzaktan eğitim [Internet-based distance education]. Akademik Bilişim Konferansları, 10 - 11 Şubat 2000, Isparta, Turkey.

Ozonur, M. \& Tekdal, M. (2004). Öğretimi ayrıntılama kuramına dayalı tasarlanan web tabanlı eşzamansız uzaktan öğretim uygulamasının üniversite öğrencilerinin akademik başarısına etkisi [The effect of web-based asynchronized distance education application based on the elaboration theory on the undergraduate students' achievement]. XIII. Ulusal Eğitim Bilimleri Kurultayı, 6-9 July 2004, Malatya, Turkey.

Pallant, J. (2007). SPSS Survival manual: A step by step guide to data analysis using SPSS for Windows ( $3^{\text {rd }}$ ed.). Berkshire: Open University Press.

Pierce, R.J. (2011). Web-based assessment settings and student achievement. Journal of Applied Learning Technology, 1(4), 28-31.

Savaş, S. \& Arıcı, N. (2009). Web tabanlı uzaktan eğitimde iki farklı öğretim modelinin öğrenci başarısı üzerindeki etkilerinin incelenmesi [Investigation of the effects of two different instructional models in web-based distance education on the student achievement]. 5. Uluslararası İleri Teknolojiler Sempozyumu (IATS'09), 13-15 May 2009, Karabük.

Sular, M. K. (2005). WEB tabanlı pedagojik formasyon eğitimi ve örnek sanal ders tasarımı ve yönetimi (Gaziantep Üniversitesi örneği) [A Web-based virtual lesson design for pedagogical formation education and its management (a sample study at Gaziantep University)]. Unpublished master thesis. Gaziantep University, Gaziantep, Turkey. 
Surry, D. W., Grubb, A. G., Ensminger, D. C., \& Ouimette, J. (2009). Implementation of web-based learning in colleges of education: barriers and enablers. Canadian Journal of Learning and Technology, 35(3), 1-18

Senyuva, E. A. (2007). Hemşirelik eğitiminde web tabanlı uzaktan eğitim uygulaması: "hasta eğitimi dersi örneği"[Implementation of web-based distance education in nursing education: "a sample lesson in patient education"]. Unpublished doctoral thesis. İstanbul University, Istanbul. Turkey.

Usluel, Y., \& Mazman, G. (2009). Adoption of Web 2.0 tools in distance education. Procedia Social and Behavioral Sciences, 1, 818-823.

Tanyeri, A. \& Tufekci, U. (2010). Bir yüksek öğretim uzaktan eğitim programının görme engellilerin kullanımı açısından değerlendirilmesi: GÜUEP örneği [Evaluation of a distant higher education program in terms of use by blind students: GÜUEP case]. International Conference on New Trends in Education and Their Implications. 11-13 November, 2010 Antalya-Turkey.

Thrasher, E. H., Coleman, P. D., \& Atkinson, J. K. (2011). Web-based versus classroombased instruction: an empirical comparison of student performance. Journal of Instructional Pedagogies, 7, 1-9. 